\title{
Zdania interrogatywne a właściwości semantyczne przysłówków sposobu
}

Słowa klucze: przysłówki sposobu, zdania interrogatywne, zdania pytające, semantyka a pragmatyka

Określenia adwerbialne, które tradycyjnie kojarzone są z pojęciem sposobu, stanowią niezwykle bogatą i zróżnicowaną klasę, a jej zakres przedmiotowy w literaturze semantyczno-składniowej wyznaczany jest nierzadko w oparciu o intuicję i bliżej niesprecyzowane kryteria. Stąd jednym z wielu wykorzystywanych przeze mnie narzędzi służących do wydobywania komponentów znaczenia interesujących mnie wyrażeń uczyniłam pytania o charakterze uzupełnień (tak nazwał je Świdziński (1993: 23), w teoriach erotetycznych Ajdukiewicza (1960: 278-280) nazywane są pytaniami do dopełnienia), które możliwie precyzyjnie charakteryzują istotę cirkumstantów związanych ze sposobem robienia czegoś/ robienia czegoś z czymś.

Przyjęta perspektywa analizy opiera się na założeniu, że pytania można traktować jako swoiste operacje metazdaniowe (Bogusławski 1977: 62-68), ponieważ służą one do aktualizacji wybranego sensu odnoszącego się w określony przez strukturę pytania sposób do tego, co przez pytanie zostało stematyzowane. Innymi słowy, oczekiwana replika winna symetrycznie odzwierciedlać strukturę tematyczno-rematyczną zdania interrogatywnego, rematem $\mathrm{w}$ analizowanych przypadkach będzie jednak predykat odnoszący 
się do rzeczywistości pozajęzykowej i spełniający wskazane pytaniem warunki kategorialne. Pytanie więc, projektując odpowiedź, wiele mówi o poszukiwanym pojęciu. Takie rozumienie istoty pytań, wywodzące się z teorii Bogusławskiego, pozwala uzasadnić kierunek analizy, w której punktem wyjścia będzie określona konstatacja z rematycznym elementem przysłówkowym, a celem dopasowanie do niej zdania interrogatywnego. Jak bowiem stwierdza Magdalena Danielewiczowa (1996: 39), odnosząc się do zaproponowanej teorii pytań:

Sensem zdania interrogatywnego nie jest kwestia istnienia pewnych bytów czy stanów rzeczy w świecie, bo to właśnie zostało raz na zawsze załatwione przez topikalizację zawartych w pytaniach zdań, które o owych bytach coś orzekają. [...] Na początku nie było pytania. Na początku było nazywanie i orzekanie o wyróżnionych obiektach najprostszych cech. Pytanie jest do pomyślenia dopiero wtedy, kiedy dane są zdania.

Analiza znaczenia pytań w koniecznym związku z ich strukturą tematyczno-rematyczną dla semantyka jest niezwykle dogodna, ponieważ dotyka problemów systemowych i w związku z tym uniezależniona jest od zagadnień zewnętrznych, jak kontekst pytania, wiedza o świece interlokutorów, moc illokucyjna aktu mowy itp. Dzięki formule wyjaśniającej sens pytania: 'Nadawca chce spowodować, żeby być skonfrontowanym z prawdziwymi zdaniami o ...' lub prościej: 'Nadawca chce uzyskać prawdziwe zdanie o...' relacja pytanie - konstatacja może być rozpatrywana w przestrzeni czysto hipotetycznej, niezależnej od aktualizujących ją aktów mowy. Nie mówi ona bowiem o rzeczywistym zachowaniu odbiorcy, ale raczej o pewnym stanie pożądanym przez nadawcę. Nie chodzi tu więc o nie-wiedzę dotyczącą tego, jaka będzie odpowiedź. W każdym przecież wypadku, gdy wypowiedź wyzwala jakąś reakcję słowną, nie można być pewnym, jaka ona będzie i jaką przyjmie formę - decydują o tym bowiem złożone kryteria pragmatyczne. Rzadko bywa tak, że odpowiedzi w pełni satysfakcjonują, prócz tego istnieją przecież tzw. pytania deliberatywne, retoryczne czy egzaminacyjne.

Intuicyjnie pytanie o sposób robienia czegoś / robienia czegoś z czymśn ${ }^{1}$ kojarzy się z zaimkiem jak, specjalizującym się niejako w wykrywaniu re-

1 Jednostkę leksykalną ktoś robi coś traktuję za Wierzbicką (2004: 8) i Bogusławskim (1994a: 39-64) jako semantycznie prostą, przy czym za Bogusławskim uznaję, że 
matów mówiących o okolicznościach realizacji czynności czy zaistnienia stanu rzeczy. To przeświadczenie zdają się potwierdzać definicje słownikowe pojęcia sposób, oparte na wskazywaniu relacji jak - tak. Zadając jednak pytanie: Jak ktoś coś robi? lub W jaki sposób ktoś coś robi?, można uzyskać szereg adekwatnych odpowiedzi, które dotyczą rozmaitych, często tylko asocjacyjnie związanych z pojęciem sposobu, circumstantów.

I tak, na pytanie: Jak Maria płynie? czy $W$ jaki sposób Maria płynie? można uzyskać odpowiedzi w rodzaju prostych replik:

(1) Maria ptynie efektownie.

(2) Maria ptynie stylem grzbietowym.

(3) Maria ptynie na grzbiecie.

(4) Maria ptynie na desce.

(5) Maria ptynie, że ho ho.,

jak i w rodzaju dłuższych opisów:

(6) Maria uczepiła się liny holowniczej, rozpaczliwie wymachuje rękami i krztuszac sie, co chwila pluje woda.

Niezależnie jednak od tego, jaką formę przyjmuje odpowiedź, jej adekwatność musi być oceniana z punktu widzenia ekwiwalencji rematów, co dane jest explicite bądź implicite (6). Nawet jeśli odpowiedzią jest dłuższy opis, nie może on mieć dowolnej struktury. Mimo to pytania z jak prowadzą do odpowiedzi, które trudno ująć w jakikolwiek schemat, w przeciwieństwie do zdań z pytajnikami: kto, co, gdzie, kiedy czy po co. Wydaje się, że przyczyna tej niejednoznaczności tkwi w samym pojęciu sposobu. Pytanie o sposób bowiem nie jest pytaniem o wyróżnienie obiektu czy stanu rzeczy, o ulokowanie ich w czasie czy w przestrzeni, bądź wreszcie o skonkretyzowanie pojedynczych ich cech, jak tempo, szybkość, głośność itp. Intencją pytającego jest uzyskanie opisu - sposób bowiem najlepiej można oddać właśnie poprzez opis. Typowymi tekstami traktującymi o sposobie są instrukcje, przepisy, relacje z przebiegu jakichś zdarzeń itp.

predykat ktoś robi coś nie jest sprowadzalny do predykatu ktoś robi coś z czymś, stąd uwzględniać będę podział na akcje ufundowane na prostym ktoś robi coś i operacje mówiące o działaniu agensa na coś poza nim samym. 
Pytając jednak:

(7) W jaki sposób pływasz?,

nikt nie oczekuje opisowej odpowiedzi w rodzaju:

(8) * Ptywam w taki sposób, że posuwam się po wodzie za pomoca rak i/lub nóg. (eksplikacja Grochowski 1973: 195)

Jak się wydaje, określenie sposobu wymaga opisu innych elementów towarzyszących, które wiążą się z czynnością komunikowaną i wpływają na jej przebieg. Czym innym bowiem jest informowanie o sposobie, a czym innym wyjaśnianie pojęcia czynności przez dodawanie do najprostszego predykatu agentywnego elementów świadczących o możliwości identyfikacji danej czynności. Prócz stałych składników każda czynność ma pewne zmienne i to właśnie one decydują o sposobie. Tę zależność obrazuje zdanie (9):

(9) Pływam, bo posuwam się po wodzie za pomoca rak i/lub nóg, mogłabym plywać żabka (tak, że leżałabym na brzuchu i wykonywatabym ramionami pótkoliste ruchy, odgarniajqc wodę na boki, a nogami odpychałabym się do tyłu i na zewnatrz - ISJP) lub kraulem (tak, że leżałabym na brzuchu, przeciagałabym pod woda raz jedno, raz drugie ramię od przodu ku tyłowi ciała $i$ wykonywałabym szybkie naprzemienne ruchy nogami, jak gdybym kopała wode - ISJP), ale wole ptywać na grzbiecie.

Opis zatem, by mógł być rozwijany linearnie, zawsze skazany jest na ułomność, ponieważ nigdy nie może być domknięty - ilość elementów wpływających nawet na najprostsze czynności jest nieskończona, stąd człowiek chcący opisać dany stan rzeczy z całą jego złożonością przypominałby Achillesa goniącego żółwia z zagadki starożytnych eleatów. Opis zatem to nic innego jak wyodrębnianie pewnych elementów najbardziej szczególnych (m.in. narzędzia, środka czynności, które przecież o samym sposobie nic nie mówią), opis również może być wynikiem rozmaitych operacji intelektualnych czy też ocen. Dlatego Barbara Boniecka (2000: 48), na podstawie badań empirycznych dotyczących interakcji na różne typy pytań, odpowiedzi na zdania interrogatywne z jak nazwała koncepcyjnymi, czyli takimi, które wyma- 
gają większego wysiłku intelektualnego. Stąd nie można w wypadku pytań tego typu wskazać tzw. odpowiedzi bezpośrednich w rozumieniu logiki pytań, czyli uznanych przez wszystkich rozumiejących pytanie za odpowiedzi najprostsze, najbardziej naturalne (Kubiński 1971: 12). Jak zauważa Jolanta Chojak (2009: 21): ,za etykietkami 'sposób' i 'ocena', powszechnie kojarzonymi z jak, kryje się być może najbardziej zagadkowy typ pytań”. Z konieczności więc, chcąc uchwycić różnice znaczeniowe przysłówków w rodzaju: efektownie, stylem grzbietowym czy na grzbiecie, należy szukać precyzujących uzupełnień. Pamiętając o tym, że reakcje odbiorców na pytania mogą być rozmaite, szukać będę określeń o tzw. maksymalnej mocy identyfikującej, które w połączeniu z jak - zdaniem potencjalnie wyodrębniać będą scharakteryzowane określenie sposobu.

I tak, wskazane przed chwilą wyrażenia adwerbialne: efektownie, stylem grzbietowym, na grzbiecie, choć odnoszą się do sposobu, zdają sprawę z hierarchii informacji o danym stanie rzeczy, o czym najlepiej uświadamia poszukiwanie racji leżących u podstaw sądów z tymi przysłówkami. $\mathrm{Na}$ podstawie tego, że w ogóle istnieje możliwość uzasadniania sądów inna niż bezpośrednia weryfikacja faktów, można wysnuć wniosek, że informacje przekazywane przez przysłówek efektownie czy wyrażenie stylem grzbietowym zostały podane niejako ex post wobec samej sytuacji:

(10) Dlaczego uważasz, że Maria ptynie efektownie?

(11) Dlaczego uważasz, że Maria płynie stylem grzbietowym?

Poprzedza ją zaś zarejestrowanie sposobu, który uległ subiektywnemu określeniu. Pytanie zaś:

\section{(12) *Dlaczego uważasz, że Maria płynie na grzbiecie?}

mogłoby być akceptowane tylko wówczas, jeśli założy się jakąś szczególną konsytuację. Oczywiście możliwe są takie konteksty, w których ktoś wnioskuje, że Maria musiała pływać na grzbiecie - chodzi jednak zawsze o pewne okoliczności zewnętrzne wobec samego sposobu wykonywania danej czynności (nie wiem, bo mnie przy tym nie byto; nie wiem, bo mi ktoś o tym nie powiedział; nie wiem, bo dokładnie nie mogłam zobaczyć, więc tylko sadzę, że było tak, a nie inaczej). Ten brak pewnej wiedzy jest jednak zawsze weryfikowalny. 
Wracając jednak do zadanych przeze mnie pytań. Pierwsze pytanie (Dlaczego uważasz, że Maria płynie efektownie?) ma charakter akcydentalny (Bogusławski 1994b: 278-280), ponieważ to, co jest wyrażone w datum quaestionis, ma subiektywny wydźwięk i dlatego można spodziewać się rozmaitych odpowiedzi, z których logicznie wynikał będzie sąd: Maria płynie i robi to efektownie dopiero, gdy na relację między poprzednikiem a następnikiem spojrzy się in extenso. Pytanie drugie zaś, choć również o charakterze eksplanacyjnym, będzie już pytaniem nieakcydentalnym, wymagającym przedstawienia takiej racji, która będzie przypadkiem (jednym z wielu) odpowiadającym temu, o czym można powiedzieć: ktoś coś robi stylem grzbietowym. Na podstawie zatem relacji między konstatacją a sądem, z którego ona wynika, można wskazać przysłówki oceniające, kwalifikujące i quasi-opisujące, czyli takie, które sposobu dotyczą bezpośrednio. Adwerbia oceniające są uzależnione od upodobań, gustu czy nierzadko emocji tego, kto próbuje określić czyjeś działanie. Kwalifikujące są wynikiem operacji myślowej służącej typizacji czyjegoś działania, quasi-opisujące zaś bezpośrednio odnoszą się do tego, jak owo działanie jest realizowane czy raczej aktualizowane.

Występowanie przysłówków mówiących o jakości sposobu robienia / zrobienia czegoś w zdaniu implikuje kontekst epistemiczny oparty na subiektywnym sądzie podmiotu, ponieważ jego wypowiedź odnosi się do takiego stanu rzeczy, który nie podlega w zwykły sposób konfrontacji z rzeczywistością (Danielewiczowa 2002: 157). Takie, a nie inne określenie sposobu jest decyzją podmiotu epistemicznego, który interpretuje rzeczywistość albo emocjonalnie, albo intelektualnie i niejako godzi się, że ktoś może sądzić inaczej. Tę zależność obrazuje brak sprzeczności w zdaniach:

(13) Jeżeli mówię, że Maria ptynie efektownie, to oceniam, że płynie właśnie tak. Ty możesz sqdzić inaczej.

(14) Jeżeli mówię, że Maria płynie stylem grzbietowym, to uważam, że ptynie wtaśnie tak. Ty możesz sqdzić inaczej.

Należy jednak zauważyć, że taka czy inna ocena będzie odnosić się do tej samej rzeczywistości pozajęzykowej. To bowiem, czy pływanie Marii nazwiemy pływaniem efektownym, czy nie, nie zmieni faktu, że Maria pływa tak, a nie inaczej. Podobnie w drugim przypadku - na podstawie tego, jak Maria pływa, jedni wnosza, że sposób pływania odpowiada stylowi grzbie- 
towemu, a drudzy nie. Z kolei określenia uznane wcześniej za quasi-opisy w swych podstawowych kontekstach wykluczają zajmowanie przez podmiot epistemiczny stanowiska, implikują zaś obiektywność, stąd dewiacja w zdaniu, w którym nadawca jest jednocześnie agensem:

(15) *Uważam, że plynę na grzbiecie.

Pytanie o jakość sposobu, by było możliwie precyzyjne, musi być więc pytaniem o ocenę:

(16) Jak wedtug ciebie plynie Maria?

Użycie frazy wedlug ciebie jednoznacznie wskazuje, że chodzi o subiektywny sąd tego, kto odpowiada. Nienaturalna wydaje się jednak odpowiedź:

(17) ?Maria plynie stylem grzbietowym.

Gdyby bowiem chodziło o odpowiedź taką jak w (17), pytający musiałby chyba zasugerować niepewność, czy pływanie Marii jeszcze odpowiada takiemu stylowi, czy już nie:

(18) Czy wedtug ciebie Maria ptynie stylem grzbietowym, czy nie?

Przysłówki dla potrzeb niniejszych rozważań nazwane kwalifikującymi są o wiele bardziej związane z samą czynnością i jej przejawami niż z oceną sposobu robienia czegoś. Motywacje ocen mogą być bardzo różne, natomiast sąd kwalifikujący musi mieć oparcie w racji, z której będzie logicznie implikowany. Wahanie, czy dana kwalifikacja jest poprawna, wynikać będzie raczej z nieostrości granic definicji. Rozumowanie można przeprowadzić w ten sposób: Maria płynie, ruchy, jakie wykonuje oraz jej ułożenie ciata wskazuja na to, że plynie stylem grzbietowym. Ptywanie Marii polega więc na tym, na czym polega pływanie stylem grzbietowym. Sformułowanie: coś polega na czymś wykorzystał A. Bogusławski, wskazując dwojaki (akcydentalny i nieakcydentalny) charakter odpowiedzi na pytanie z dlaczego (Bogusławski 1994b: 280). Wymaga ono relacji logicznego wynikania między sądem a jego racją. Jednocześnie zaznaczyć należy, że chodzi tu o pewną cechę 
bądź cechy istotne, kluczowe, ujmujące sposób czynności jako całość. Jeśli bowiem coś polega na czymś, to (wg ISJP) jest to jego istota czy podstawa lub ma w tym swoje wyttumaczenie czy swoja przyczynę (np. Praca moja polegała na segregowaniu dokumentów i przyjmowaniu telefonów... Wolność polega na dokonywaniu wyborów. Wielkość tego pisarza polega na niezwykłości jego języka). Między sposobem więc a tym, że cośl polega na czymś2, zachodzi ważna relacja pojęciowego przetworzenia tego, co dane empirycznie, w formułę o ogólnym charakterze. Pytanie jednak:

(19) Na czym polega ptywanie Marii. / Na czym polega to, jak Maria plynie.

nie jest adekwatne do fraz trzeciego typu, tj. na grzbiecie, na brzuchu, na wznak itp. Dewiacyjne bowiem są odpowiedzi w rodzaju:

(20) *Ptywanie Marii polega na tym, że Maria płynie na grzbiecie.

(21) *Zmywanie podtogi przez Pawła polega na tym, że Paweł zmywa podłoge na czworakach.

Choć akceptowalne jest:

(22) Maria plynie w taki sposób, że płynie na grzbiecie.

Quasi-opisy ze względu na omawianą wyżej cechę wyróżniania pewnych podczynności czy przyjmowanej pozycji w czasie realizacji czynności nie są wystarczające, by stać się dopełnieniem frazy cośl polega na czymś2. Choć mówią o sposobie, wskazują jedynie na pewną część możliwego opisu, pewną okoliczność modyfikującą charakter danej czynności, ale na pewno nie będąca jej istotą. Zmywanie podłogi nie polega przecież na robieniu tego na kolanach. Tego typu informacje o sposobie kojarzone będą raczej z formą, kształtem, z tym, jak się ona przejawia, czy po czym daje się poznać. Nie jest to skojarzenie tak odległe, jak by się mogło wydawać. Linde (1854-1860) na przykład wymienia kształt jako pierwszy w artykule hasłowym odnoszącym się do sposobu, podobnie Doroszewski (1958-1969), choć zaznacza, że to znaczenie jest przestarzałe ( $Z$ tej to powiastki morat w tym sposobie, że jak ty komu, tak on tobie. Fredro A. Jow. 268). Wydaje się więc, że quasi-opisy prze- 
kazują informację o przejawach czynności, czyli o tym, jak sposób wykonywania czynności się uzewnętrznia.

Sedna problemu wydaje się dotykać pytanie:

(23) ?W czym przejawia się plywanie Marii / to, że Maria pływa? W tym, że robi to na grzbiecie.

(24) ?Zmywanie podtogi przez Pawła przejawia się w tym, że Pawet robi to na kolanach.

Jednostka coś przejawia się w czymś informuje wg Innego słownika języka polskiego (Bańko 2000) o tym, jaką formę coś przybiera, po czym daje się poznać. W czasie robienia czegoś agens przybiera jakąs pozycję, jedną z wielu, aktualizując w ten sposób czynność. Nienaturalność jednak zdań (23) i (24) zdaje sprawę z tego, że odnalezienie ogólnej formuły pytań w języku naturalnym charakteryzujących $\mathrm{w}$ datum questionis quasi-opis nie jest możliwe. Uzyskanie informacji, że ktoś coś robi na grzbiecie czy na kolanach, wymagałoby pytania o pozycję, jaką przyjmuje agens w czasie wykonywania czynności. To zaś uświadamia, że poszukiwanie wyrażeń przysłówkowych o cechach quasi-opisów wymaga każdorazowego uściślania w datum questionis tego, co one wyrażają.

Jak z powyższych rozważań wynika, poszukiwanie zdań interrogatywnych, których treść zawarta w datum questionis może być skonfrontowana z treścią badanych przysłówków, istotnie zbliża semantyka do określenia struktury pojęciowej badanych wyrażeń. Wyznacza również granice między tym, co należy do systemu, a tym, co realizowane jest w rzeczywistych aktach mownych.

\section{Bibliografia}

Ajdukiewicz K., 1960, Zdania pytajne, w: tenże, Język i poznanie, t. 1, Warszawa: Wydawnictwo Naukowe PWN, s. 278-287.

BogusŁawski A., 1977, On the Semantic Structure of Interrogative Sentences, przedruk w: tenże, Sprawy słowa, Warszawa: Veda, s. 297-302.

BogusŁawski A., 1994a, Semantic Primes for Agentive Relations, przedruk w: tenże, Sprawy stowa, Warszawa: Veda, s. 330-352. 
BogusŁaWski A., 1994b, „*Dlaczego wiemy, za co powinniśmy kochać pana profesora?" - Dlaczego?*, przedruk w: tenże, Sprawy słowa, Warszawa: Veda, s. 276-289.

Boniecka B., 2000, Struktura i funkcje pytań w języku polskim, Lublin: Wydawnictwo UMCS.

Chолак J., 2009, Zrozumieć „jak”: studium semantyczno-składniowe, Warszawa: BEL Studio.

Danielewiczowa M., 1996, Charakterystyka struktury tematyczno-rematycznej wypowiedzeń interrogatywnych, Warszawa: Wydawnictwo UW.

Danielewiczowa M., 2002, Wiedza i niewiedza: studium polskich czasowników epistemicznych, Warszawa: Wydawnictwo UW.

Doroszewski W. (red.), 1958-1969, Słownik języka polskiego, Warszawa: Państwowe Wydawnictwo „Wiedza Powszechna”, PWN.

Grochowski M., 1973, Eksplikacje znaczeń czasowników ruchu, w: M. R. Mayenowa (red.), Semiotyka i struktura tekstu, Wrocław: Zakład Narodowy im. Ossolińskich - Wydawnictwo Polskiej Akademii Nauk, s. 189-199.

ISJP: BAŃKo M. (red.), 2000, Inny słownik języka polskiego, t. 1-2, Warszawa: Wydawnictwo Naukowe PWN.

Kubiński T. 1971, Wstęp do logicznej teorii pytań, Warszawa: PWN.

Linde S. B., 1854-1860, Słownik języka polskiego, Lwów: Zakład Narodowy im. Ossolińskich.

Świdziński M., 1993, Semantics of indirect questions in Polish, Warszawa: Dom Wydawniczy i Handlowy „Elipsa”.

WierzBicka A., 2004, Jak można mówić o Trójcy Świętej w słowach prostych $i$ uniwersalnych, Lublin: Wydawnictwo UMCS.

\section{The interrogative sentences in the context of semantic features of adverbs describing the way of doing something}

( s u m m a r y)

The article concentrates on the problem that was discussed at the conference „Synchronia i diachronia - zbliżenia i dialogi”, i.e. the boundary line between the language system and the use of language. This issue occurs when interrogative sentences are analyzed. When somebody asks someone about the way of doing something, they cannot predict the interlocutor's reaction. However, this remark refers to each utterance which requires one's verbal reaction. This is why from the semantic viewpoint the equivalence of the thematic-rhematic structure of interrogative and affirmative sentences must be assumed. According to this theory each interrogative sentence determines the rheme of the reply. From which it appears that questions say a lot about the semantic structure of search terms, e.g. the best question about ad- 
verbs of manner expressing an opinion is: Jak wedtug ciebie ktoś coś robi. Whereas the most adequate question about adverbs of manner qualifying samobody's activity is: Na czym polega sposób, w jaki ktoś coś robi? And finally, the third group concenrs adverbs of manner expressing the circumstances of somebody's activity. Their characteristic feature is saying something about what can be verified in reality. The appropriate question about these adverbs is: W czym przejawia się to, że ktoś coś robi. 